\title{
When Your Country Cannot Care for Itself: A Filipino Feminist Critique of Care-based Political Theories
}

Noelle Leslie G. Dela Cruz

\begin{abstract}
In this paper, I evaluate a number of care-based political theories, whose central project is to identify, frame, and address the socalled crisis of care. Three proposals emerge, which I characterize as the philosophical, economic, and political solutions. In light of recent transnational analyses, however, these solutions appear to be inadequate in addressing the global nature of the problem. Thus, there is a need to revise the political philosophy of care. To this end, I identify a set of preliminary questions to ask based on a careful consideration of the Philippine situation.
\end{abstract}

Keywords: care work, care ethics, social justice, transnational feminism

$\mathrm{A}$ $\mathrm{n}$ irony familiar to many Filipinos is how their country is a prime exporter of care workers and yet there is a manifest dearth of carers sociologist and prominent researcher on Filipina migrant labor,

care work is now one of the largest exports and sources of foreign currency for the country .... As a result of the systematic extraction of care from the Philippines, a great number of children there are growing up without the physical presence of their (migrant) parents. ${ }^{1}$

This crisis points to the important philosophical work of laying down the foundations for a care-based political theory that is applicable in the

${ }^{1}$ Rhacel Salazar Parreñas, "Patriarchy and Neoliberalism in the Globalization of Care," in The Force of Domesticity: Filipina Migrants and Globalization (New York and London: New York University Press, 2008), 46.

(c) 2020 Noelle Leslie G. Dela Cruz

https://www.kritike.org/journal/issue 26/dela cruz june2020.pdf

ISSN 1908-7330

(cc) $\mathrm{BY}-\mathrm{NC}-\mathrm{ND}$ 
Philippine context. However, existing studies addressing specifically Philippine problems tend to forego a detailed analysis of care work, focusing instead on materialist or postmodern critiques. ${ }^{2}$ While these are useful theoretical lenses that bring out the salience of class factors and power discourses, care cannot simply be reduced to economic labor ${ }^{3}$ or to a disciplinary technology. Such analyses neglect care's relational nature and its origins in women's experience. On the other hand, turning to the most fully developed accounts of political theory that draw on feminist care ethics, one finds that these tend to be western-centered, mainly addressing the concerns of liberal societies in the Global North. ${ }^{4}$ There is a need to put these political proposals in dialogue with the Philippine situation, inasmuch as the care crisis is undeniably a worldwide phenomenon, one in which women from developing countries suffer the most. As Parreñas evocatively puts it in her description of the devaluation of care,

... the ideology of women's domesticity works to the disadvantage of the Philippines as a nation, because the low pay of Filipino women signifies the low pay of the Philippines in the global economy. ${ }^{5}$

In this paper, I evaluate the key claims of a number of care-based political theories, with a view to identifying gaps that may be filled through a consideration of the Philippine situation. In so doing, I hope to formulate the main questions that should be addressed on the way toward a care-based political theory that is applicable to the Filipino setting. It is my hope that the discussion would contribute to new ways of thinking about the global nature of care work and what this says about the prospects for a transnational feminism.

\footnotetext{
${ }^{2}$ See for example Anne E. Lacsamana, Revolutionizing Feminism: The Philippine Women's Movement in the Age of Terror (New York and London: Routledge, 2012); Robyn Magalit Rodriguez, Migrants for Export: How the Philippine State Brokers Labor to the World (Minnesota: University of Minnesota Press, 2010); James A. Tyner, Made in the Philippines: Gendered Discourses and the Making of Migrants (London and New York: RoutledgeCurzon, 2004).

${ }^{3}$ Selma Sevenjuijsen, Citizenship and the Ethics of Care: Feminist Considerations on Justice, Morality and Politics (London and New York: Routledge, 1998).

${ }^{4}$ See Joan C. Tronto, Caring Democracy: Markets, Equality, and Justice (New York and London: New York University Press, 2013); Daniel Engster, The Heart of Justice (Oxford: Oxford University Press, 2007), Kindle; Daniel Engster, Justice, Care, and the Welfare State (Oxford: Oxford University Press, 2015); Eva Feder Kittay, Love's Labor: Essays on Women, Equality, and Dependency (New York and London: Routledge, 1999); Virginia Held, The Ethics of Care: Personal, Political, and Global (Oxford: Oxford University Press, 2006); Nel Noddings, Starting at Home: Caring and Social Policy (Berkeley, Los Angeles, and London: University of California Press, 2002).

${ }^{5}$ Rhacel Salazar Parreñas, "Gender Ideologies in the Philippines," in The Force of Domesticity, 38.
}

(c) 2020 Noelle Leslie G. Dela Cruz https://www.kritike.org/journal/issue 26/dela cruz june2020.pdf ISSN 1908-7330 


\section{FEMINIST CRITIQUE OF CARE-BASED POLITICAL THEORIES}

\section{Defining and Politicizing Care}

Fine notes that in ordinary language, "care" has at least three main senses: as a mental disposition, as an activity or form of work, and as a relationship between individuals or groups. ${ }^{6}$ All three connotations are involved in theories of care work-sometimes referred to as dependency work - that have emerged separately from two main discourses: the womancentered American feminism of the 1980s, on one hand, and disability studies, on the other. ${ }^{7}$

The feminist ethics of care has its roots in Carol Gilligan's landmark critique of psychologist Lawrence Kohlberg's theory of moral development. She contested Kohlberg's privileging of an ethics of universal principles over an ethics of relationships, arguing that these distinct ways of moral reasoning-justice and care-reflect the gendered socialization of boys and girls. ${ }^{8}$ However, it was Joan C. Tronto's work that transformed Gilligan's feminine-centered view of care into a fully developed feminist theory. In other words, Tronto shifted the debate about care ethics from the issue of gender difference to its adequacy as a moral and political theory. ${ }^{9}$ This augured the politicization of the ethics of care, which has led to its application to social issues by such philosophers as Eva Kittay, Daniel Engster, Nel Noddings, Virginia Held, and Fiona Robinson.

The central project of a care-based political theory is the identification, framing, and addressing of the so-called "crisis of care." This crisis is a product of demographic trends that may be attributed to modernization. More women joining the workforce means a diminishing pool of individuals who traditionally perform the work of caring in the domestic sphere. Far from ending gender inequality, this modern development has resulted in the so-called "second shift" for women. Due to cultural expectations, women find themselves having to perform caring work in addition to work outside the home. According to a 2018 study by the International Labor Organization, "Women perform 76.2 per cent of the total amount of unpaid care work, 3.2 times more than men." Furthermore, "in no country in the world do men and women provide an equal share of unpaid

\footnotetext{
${ }^{6}$ Michael Fine, "Eva Feder Kittay: Dependency Work and the Social Division of Care," in The Palgrave Handbook of Social Theory in Health, Illness and Medicine, ed. by Fran Collyer (New York: Palgrave Macmillan, 2015), 631.

7 Michael Fine and Caroline Glendinning, "Dependence, Independence or Interdependence? Revisiting the Concepts of 'Care' and 'Dependency,'” in Aging and Society, 25:4 (July 2005), 602.

${ }^{8}$ Kirstein Rummery and Michael Fine, "Care: A Critical Review of Theory, Policy and Practice," in Social Policy \& Administration, 46:3 (2012), 321-343.

${ }^{9}$ Joan C. Tronto, "Beyond Gender Difference to a Theory of Care," in Signs: Journal of Women in Culture and Society, 12:4 (1987), 646.

(c) 2020 Noelle Leslie G. Dela Cruz

https://www.kritike.org/journal/issue 26/dela cruz june2020.pdf

ISSN 1908-7330
}

(c) BY-NC-ND 
care work." 10 If they have class privilege, some women are able to afford to pass on their reproductive labor to other women from socially disadvantaged groups. Ultimately, this means that "Most care workers are women, frequently migrants and working in the informal economy under poor conditions and for low pay." 11

Before examining key proposals from care-based political theories, let us first delve deeper into the meaning of "care work." A useful and frequently cited definition is one by Tronto and Berenice Fisher: "a species activity that includes everything we do to maintain, continue, and repair our 'world' so that we can live in it as well as possible." 12 The advantage of this definition is that it is broad enough to include two overlapping activities, namely: "direct, personal and relational care activities, such as feeding a baby or nursing an ill partner; and indirect care activities, such as cooking and cleaning." 13 Nancy Folbre has produced a comprehensive table of care work that identifies four main categories running the gamut from unpaid work to paid employment; divided into two types (direct and indirect); and which may be performed for any of five specific recipients, namely, children, the elderly, the sick and disabled, adults other than the self, and the self. ${ }^{14}$

Other definitions of care work are narrower, focusing on the direct kind. For example, Kittay defines "dependency work," which she elsewhere refers to as "dependency care," 15 as the work of caring for those who are inevitably dependent. ${ }^{16}$ This definition excludes personal services, such as massage therapy or yoga instruction, which are provided to adults who are not inevitably dependent. Meanwhile, Engster qualifies Tronto's definition which he argues is too broad. For him, caring is

everything we do directly to help individuals meet their basic needs, develop or maintain their basic capabilities, and live as much as possible free from suffering, so that

${ }^{10}$ Laura Addati, Umberto Cattaneo, Valeria Esquivel, and Isabel Valarin, Executive Summary to Care Work and Care Jobs for the Future of Decent Work (Geneva: International Labour Office, 2018), xxxix.

11 Ibid., xxvii.

12 Tronto, Caring Democracy, 19.

${ }_{13}$ Addati, Cattaneo, Esquivel, and Valarin, Executive Summary to Care Work and Care Jobs for the Future of Decent Work, xxvii.

${ }^{14}$ Nancy Folbre, "Measuring Care: Gender, Empowerment, and the Care Economy," in Journal of Human Development, 7:2 (2006), 188.

${ }^{15}$ Eva Feder Kittay, Bruce Jennings, and Angela A. Wasunna, “Dependency, Difference and the Global Ethic of Longterm Care," in The Journal of Political Philosophy, 13:4 (2005), 443.

${ }^{16}$ Kittay, Preface to Love's Labor, ix.

(c) 2020 Noelle Leslie G. Dela Cruz https://www.kritike.org/journal/issue 26/dela cruz june2020.pdf ISSN 1908-7330 


\author{
they can survive and function at least at a minimally \\ decent level .... ${ }^{17}$
}

Such a definition excludes practices that may help "to maintain, continue, and repair our 'world,'" such as house building and plumbing, which are not caring activities per se though they may be caring in their aim and virtues. ${ }^{18}$ Unlike Kittay, Engster makes no distinction between necessary care and personal services. ${ }^{19}$

For the purposes of this paper, I shall adopt the broader definition, as it better captures the reproductive labor performed by Filipino women. According to Parreñas, reproductive labor is wider than (direct) care work, since it includes such tasks as "purchasing household goods, preparing food, laundering clothes, dusting furniture, sweeping floors, maintaining community ties, caring for adults and children, socializing children, and providing emotional support." 20 Parreñas criticizes the traditional definition of care work, which emphasizes the experiences of privileged women and excludes the so-called "dirty" or menial work usually performed by migrant care workers or women from socially disadvantaged groups. ${ }^{21}$

In sum, this section has traced the development of care ethics from the women's movement and disability studies, and then shown howthrough the pioneering work of Tronto-the concept of care has been incorporated into political theory. As my paper is primarily concerned with a broad evaluation of care-based political theories, it was necessary to show the provenance of this type of perspective, as well as to qualify my definition of "care work."

\footnotetext{
${ }^{17}$ Daniel Engster, "Rethinking Care Theory: The Practice of Caring and the Obligation to Care," in Hypatia: A Journal of Feminist Philosophy, 20:3 (Summer 2005), 54.

${ }_{18}$ Ibid., 56.

${ }^{19}$ Ibid., 57.

${ }^{20}$ Rhacel Salazar Parreñas, "The Reproductive Labour of Migrant Workers," in Global Networks, 12:2 (2012), 270.

${ }^{21}$ Hanes offers a similar criticism of the traditional definition of care work. According to him, the concept of care has been valorized as an Other to male-dominated concepts and activities. As a result of this valorization, it ignores other, "non-caring" forms of labor that women do-for example, feminized commodity production-which are underpaid, exploited, and excluded from politics. For him, the care/non-care division of feminized labor reproduces hierarchies among women. In light of the expanded definition of "care" that I am adopting in this paper, however, the division Hanes identified is more appropriately captured by the direct/indirect opposition between types of care work. See Douglas William Hanes, "Left Out/Left Behind: On Care Theory's Other," in Hypatia: A Journal of Feminist Philosophy, 32:3 (May 2017), 523-539.
}

(c) 2020 Noelle Leslie G. Dela Cruz https://www.kritike.org/journal/issue 26/dela cruz june2020.pdf ISSN 1908-7330

(c) BY-NC-ND 


\section{Framing the Care Crisis}

In addressing the care crisis, philosophers associated with the major care-based political theories have offered similar diagnoses of what is wrong with liberal democratic societies and similar proposed solutions. They also share blind spots that, I argue, may be corrected through a more global perspective that recognizes the plight of developing countries such as the Philippines.

We may begin with the care-based critique of the liberal state as being founded on an erroneous assumption about human nature. Liberalism, with its values of equality and freedom, relies upon universalist moral principles. These presume moral subjects to be independent or autonomous actors making rational choices in a free market. For example, John Rawls's theory of justice, which applies Kantian deontology to the political realm, presumes that in a hypothetical original position, people would rationally opt for the fairest possible society. However, in light of Thomas Piketty's analysis of the contemporary trend of rising social inequality, the ideal of justice has clearly not come to pass. ${ }^{22}$

The care crisis is one pervasive instance of injustice. In the postEnlightenment world, there remains an inequitable distribution of care responsibilities between women and men. Even though women have long since joined men in the public sphere, the values associated with the public and private realms remain hierarchically gendered. Care is still traditionally relegated to the domestic sphere, the sphere of so-called "women's work," which is thought to have little or no economic value. Thus, those who perform care work are either not paid for it or are paid comparatively little. Professional working women assume the burden of care responsibilities in the home. If they are economically privileged, they pass these responsibilities on to other women who need the work, which pays far less than other types of jobs in the labor market.

The care deficit has a pernicious effect on freedom and equality. Tronto sees it as intertwined with what she calls the "democracy deficit," or the incapacity of governments to reflect the values and ideas of their citizens. Because of the disproportionate burden of care, not all citizens can equally exercise their political rights. ${ }^{23}$ For example, instead of being able to attend a political referendum, some have to stay home and take care of a bedridden elderly parent. Or instead of being able to read the news, some have had to forego schooling in order to economically support their younger siblings.

\footnotetext{
${ }^{22}$ Engster, Justice, Care, and the Welfare State, 5.

${ }^{23}$ Tronto, Caring Democracy, 17-18.
} 
Tronto concludes that the move toward democratic inclusion through paid work has left unanswered the question of who does the care work. ${ }^{24}$

Kittay and Noddings share Tronto's critique of liberalism. For Kittay, "[a] conception of society viewed as an association of equals masks inequitable dependencies, those of infancy and childhood, old age, illness and disability." ${ }^{25}$ Meanwhile, Noddings observes that liberalism begins from the wrong start, i.e., the thoughts and actions of mature rational beings who make unencumbered choices in order to satisfy their needs and wants. Such an erroneous assumption about how people actually are over a great deal of their life spans leads to dilemmas of freedom and equality. ${ }^{26}$ By contrast, a carebased political and moral position begins not with independence or autonomy, but with dependency. Engster considers dependency to be the ground of our obligation to care. We must care for others, not because they are vulnerable to us, but because we are dependent (and have been or will be) on others. ${ }^{27}$ This entails that care is foundational to justice and that values such as freedom and equality are secondary to care. ${ }^{28}$ In other words, freedom and equality can only be realized in a caring society. ${ }^{29}$

A number of interrelated proposals have been put forward in order to achieve such a caring society, which may be summarized as follows: (1) recognizing the fundamental value of care, and equal participation in care work; (2) creating a robust welfare state in which care, rather than being privatized or commoditized, is seen as a public responsibility; and (3) adopting a critical attitude toward the traditional public/private split, such that the values associated with either sphere are seen not in opposition to, but in harmony with, each other. I consider these to be the philosophical, economic, and political solutions, respectively.

\section{The Philosophical Solution: Recognizing the Value of Care}

Drawing on the tradition of disability studies, Kittay, Jennings, and Wassuna propose a transvaluation of dependency, in which it is seen not as

\footnotetext{
${ }^{24}$ Ibid., 26.

${ }^{25}$ Kittay, Preface to Love's Labor, xi.

${ }^{26}$ Noddings, Starting at Home, 77.

27 Engster, "Rethinking Care Theory: The Practice of Caring and the Obligation to Care," 59.

${ }^{28}$ Engster, Justice, Care, and the Welfare State, 29.

${ }^{29}$ Engster notes that although care theory has commonalities with communitarianism, in that they both value interconnectedness and view moral obligations as nonvoluntary, care theory nonetheless departs from it in important ways. Unlike communitarian theories, care theory recognizes an independent moral criterion-i.e., the practice of caring-for judging the validity of institutions and traditions. Also, its aim is not so much to strengthen communal ties or promote social solidarity as ends in themselves, but to ensure a basic level of care for all. See
} Engster, The Heart of Justice.

(c) 2020 Noelle Leslie G. Dela Cruz https://www.kritike.org/journal/issue 26/dela cruz june2020.pdf ISSN 1908-7330

(c) BY-NC-ND 
a deficiency or problem, but as an opportunity for flourishing. ${ }^{30}$ Thus, dependency care is not menial work that no one powerful should want to do, but a vital task that empowers all of us. Meanwhile for Tronto, the meeting of caring needs is the very basis of equality; democratic caring means we are equal in being care receivers. ${ }^{31}$ The moral quality she calls "caring with" embodies what it means to be a citizen in a democracy, which is to care for citizens and to care for democracy itself. ${ }^{32}$

\section{The Economic Solution: Creating a Robust Welfare State}

In keeping with its intrinsic universal value, care is a matter of public interest. The equitable distribution of caring responsibilities is thus a question of social justice. Accordingly, in The Heart of Justice, Daniel Engster advocates government action in facilitating the care of dependents, such as in parenting, education, health care, elder care, etc. After all, government is our best means to enforce the duty to care for everyone, since only government can effectively assure peace, security, and protection. It can coordinate care and compel people to contribute their fair share of caring work. ${ }^{33}$ For their part, Kittay, Jennings, and Wasunna introduce the principle of doulia, ${ }^{34}$ according to which "[j] ust reciprocal relations require that a third party provide for the caregiver what neither the cared for nor carer can provide for herself as she turns her attention to the cared for." 35 Their important contribution to care ethics is the addition of a third subject position to the traditional care workercare recipient dyad, i.e., "the provider," or the one who cares for the carer, mainly through economic means. In a robust welfare state, government plays the paradigmatic role of provider.

Since care is a public interest, care theorists reject the neoliberal trend of privatizing care. Tronto characterizes neoliberalism, which favors freemarket capitalism, as a "disastrous worldview." It wants to reduce the state's care costs, sees people as workers and consumers who already have autonomy and clear ideas about their preferences, and makes care into a private matter. ${ }^{36}$ According to Tronto, "[w]hen unequal citizens only care privately, they deepen the vast inequalities and the exclusion of some from

\footnotetext{
${ }^{30}$ Kittay, Jennings, and Wasunna, "Dependency, Difference and the Global Ethic of Longterm Care," 468.

31 Tronto, Caring Democracy, 29.

32 Tronto, Preface to Caring Democracy, $\mathrm{x}$.

${ }^{33}$ Held, The Ethics of Care, 270.

${ }^{34}$ Kittay coins the term doulia from the Spanish word for the postpartum caregiver, the doula, who cares for the mother as the mother cares for the newborn.

${ }^{35}$ Kittay, Jennings, and Wasunna, "Dependency, Difference and the Global Ethic of Longterm Care," 460.

36 Tronto, Caring Democracy, 38-40.
}

(c) 2020 Noelle Leslie G. Dela Cruz https://www.kritike.org/journal/issue 26/dela cruz june2020.pdf ISSN 1908-7330 
the real prospects of being full citizens." ${ }^{37}$ Held adopts a similar stance, claiming that the exchange or market value of caring work is one of the least appropriate ways to think of its value. ${ }^{38}$ Running on the principle of profit maximization, the market cannot adequately promote the value of caring concern, which is integral to an array of human practices: for example, education, child care, health care, culture, and the protection of the environment. ${ }^{39}$ However, this does not mean that she opposes paid care work. She writes,

We can grant that of course caring labor deserves not only decent but excellent pay without agreeing that the expansion of the market is usually or inherently appropriate or justifiable or liberating. Often it is not. ${ }^{40}$

Kittay echoes Held's view. While care work should be compensated, serious moral difficulties arise when care is considered to be a commodity like any other. The problem is that care is not fungible, for it matters who cares for whom. ${ }^{41}$ The issue of the commodification of care is beyond the scope of this paper, but the ambivalence expressed by Kittay and Held points to statesponsored care as the morally preferable solution to the care crisis, as opposed to privatization or marketization. ${ }^{42}$

\section{The Political Solution: Adopting a Critical Solution Using a Private/Public Split}

The two proposals so far discussed already constitute an implicit critique of the traditional opposition between the public and private spheres, or matters considered to be "political" as opposed to "personal" - to allude to a major Second Wave feminist slogan. Recognizing the universal value of care raises work of an intimate and relational nature to the level of public concern, and hence a matter for which government must assume a great degree of responsibility. In her radical application of care ethics to social theory, Noddings further demonstrates the porous border between "public" and "private." Her main thesis is that a number of values and attitudes

\footnotetext{
37 Ibid., 96.

${ }^{38}$ Held, The Ethics of Care, 109.

39 Ibid., 120.

40 Ibid., 109.

${ }^{41}$ Eva Feder Kittay, "The Global Heart Transplant and Caring Across National Boundaries," in The Southern Journal of Philosophy, XLVI (2008), 149.

${ }^{42}$ For a nuanced investigation of the commodification of care, see Rutger Claassen, "The Commodification of Care," in Hypatia: The Feminist Journal of Philosophy, 26:1 (2011), 43-64. 
learned in the ideal home may be carried over to the wider world. Consider the basic attitude encapsulated by the response, "I am here." A social policy that is guided by this basic attitude "would reject any principle or rule that makes it impossible for people in responsible positions to respond with care to those who plead for care or obviously need it." 43 A world that turns on the values of the ideal home emphasizes process rather than fixed goods; insists on caring relations as fundamentally good; justifies intervention in certain situations in order to prevent harms to self as well as harms to others; and favors policies that allow choices, though these choices are collaborative and are not anchored in rights. ${ }^{4}$

In sum, feminist applications of care ethics to political and social theory, which primarily identify and address the crisis of care, constitute a major criticism of the prevailing order of neoliberal capitalism. However, recent transnational analyses ${ }^{45}$ have exposed their insularity and failure to address concerns beyond the paradigmatic liberal nation-state. These critiques situate the care crisis in the context of globalization, citing empirical studies that reveal the stark inequalities in north-south relations. As the care deficit in developed countries is filled by migrant workers from poor countries, it becomes clear that the "pass-on" approach to care transcends national boundaries: "Care in our society is passed on from men to women to poorer and yet poorer women, from wealthy nations to poorer and yet poorer nations." 46 Indeed, there is copious literature on "global care chains," a phrase coined by Arlie Russell Hochschild based on the work of Rhacel Salazar Parreñas, who refers to the phenomenon as "the international division of reproductive labor." This refers to

the three-tier transfer of reproductive labor among women in sending and receiving countries of migration. Whereas class-privileged women purchase the lowwage household services of migrant Filipina domestic workers, these women simultaneously purchase the

${ }^{43}$ Noddings, Starting at Home, 231.

${ }^{44}$ Ibid., 241.

${ }^{45}$ See Olena Hankivsky, "Imagining Ethical Globalization: The Contributions of a Care Ethic," in Journal of Global Ethics, 2:1 (August 2006), 91-110; Parvati Raghuram, "Locating Care Ethics Beyond the Global North," in ACME: An International Journal for Critical Geographies, 15:3 (2016), 512-533; Allison Weir, "Global Care Chains: Freedom, Responsibility, and Solidarity," in The Southern Journal of Philosophy, 46 (2008), 166-175; G.K.D. Crozier, "Care Workers in the Global Market: Appraising Applications of a Feminist Care Ethics," in The International Journal of Feminist Approaches to Bioethics, 3:1 (Spring 2010), 113-137; Lise Widding Isaksen, Sambasivan Uma Devi, and Arlie Russell Hochschild, "Global Care Crisis: A Problem of Capital, Care Chain, or Commons?" in American Behavioral Scientist, 52:3 (2008), 405-425.

${ }^{46}$ Weir, “Global Care Chains," 171.

(c) 2020 Noelle Leslie G. Dela Cruz

https://www.kritike.org/journal/issue 26/dela cruz june2020.pdf

ISSN 1908-7330

(cc) BY-NC-ND 


\author{
even lower-wage household services of poorer women \\ left behind in the Philippines .... ${ }^{47}$
}

Thus, from a transnational perspective, feminist care-based political theories, such as Tronto's citizenship model of care, overlook "the most significant harm," i.e., the care drain in developing countries. ${ }^{48}$ The "push" and "pull" factors motivating south-to-north migration are products of global capitalism, and unless these are recognized, "it will not be possible to address the needs of those who are truly worst off in this global care regime-those in the source countries who need care." 49 Isaksen, Devi, and Hochschild characterize this problem in terms of the erosion of the "commons" of the South, which is the real injury of global capital: the distortion and erosion of the family ties of the South in order to support the market of the North. ${ }^{50}$

\title{
The View from the Philippines
}

In the preceding section, I have identified at least three main proposals from the major care-based political theories, while also showing that these may be inadequate in addressing the larger problem of the global care crisis. A revision of the political philosophy of care is thus in order. ${ }^{51}$ To this end, a careful consideration of the Philippine situation may point the way to relevant moral and political questions.

According to Parreñas:

47 Rhacel Salazar Parreñas, “The International Division of Reproductive Labor," in Servants of Globalization: Migration and Domestic Work, 2nd ed. (Stanford: Stanford University Press, 2015), 29.

${ }^{48}$ Crozier, "Care Workers in the Global Market," 127.

49 Ibid., 131.

${ }^{50}$ Isaksen, Devi, and Hochschild, "Global Care Crisis," 419.

${ }^{51}$ In more recent works, Kittay mentions the problem of global care chains and refers to Parreñas's extensive study of Filipina migrant care workers. (See Kittay, "The Global Heart Transplant.") Thus, she points to the obligations of rich nations to poor nations as caregiving and care workers across national boundaries; identifies four key questions for a global ethics of care; and highlights the dependency-related hardships suffered in particular by women of the Global South. (See Kittay, Jennings, and Wasunna, "Dependency, Difference and the Global Ethic of Longterm Care."). However, these preliminary remarks are far from a fully developed "global ethics of care" that can be on par with her Love's Labor: Essays on Women, Equality, and Dependency (1999). In regard to the possibility of such a study, Fiona Robinson's Globalizing Care: Ethics, Feminist Theory, and International Relations (1999) fills the gap in care ethics in an international context. [See Fiona Robinson, Globalizing Care: Ethics, Feminist Theory, and International Relations (Boulder: Westview Press, 1999).]. However, its main concern is international relations. There remains a lack in care-based political theory of a philosophical study that specifically and fully addresses the care crisis in the context of the Global South.

(C) 2020 Noelle Leslie G. Dela Cruz

https://www.kritike.org/journal/issue 26/dela cruz june2020.pdf

ISSN 1908-7330

(c) $\mathrm{BY}-\mathrm{NC}-\mathrm{ND}$ 
A culture of emigration is pervasive in the Philippines. Migrants include land- and sea-based workers. Women primarily work on land, and the majority of them are domestic workers like nannies, housecleaners, and caregivers for the elderly .... Filipina women are the domestic workers par excellence of globalization. ${ }^{52}$

The incapacity of the Philippine economy to provide jobs for Filipinos may be traced back to the country's long history of exploitation by colonizers, in particular the United States, with which it remained stuck in a neocolonial relationship long after independence was granted in 1946. Today, more than a quarter of Filipinos fall below the lower middle income poverty line of $\$ 3.20$ per day. ${ }^{53}$ The Philippines, like other countries in the Third World, "exemplifies the failures of over two decades of neoliberal economic globalization policies." 54 As preconditions for granting loans, financial institutions such as the International Monetary Fund and the World Bank have imposed structural adjustment programs on developing counties. To ensure the priority of debt servicing, these measures force governments to cut down on social programs, liberalize trade, encourage the exportation of certain agricultural products, devalue the local currency, and privatize state enterprises. These measures "open up developing nations' economies and peoples to imperialist exploitation," hence leading to poverty-driven outmigration. ${ }^{55}$

Relying on the remittances of overseas workers to keep its economy afloat, the Philippines maintains an aggressive labor export policy. Lacsama blames the Marcos regime for the eventual development of this exploitative practice. Its more than two decades of reckless economic strategies and rampant graft and corruption exacerbated the debt burden first incurred by the Macapagal administration, which took out a $\$ 300$ million stabilization loan in 1962. ${ }^{56}$ As of March 2018, the Philippines' external debt stands at \$73.2

\footnotetext{
52 Rhacel Salazar Parreñas, “The Global Migration of Filipino Domestic Workers," in Servants of Globalization, 2.

${ }^{53}$ Ralf Rivas, "Persistent high inflation may slow down poverty reduction - World Bank," in Rappler (4 October 2018), <https://www.rappler.com/business/213517-high-inflationslow-down-poverty-reduction-world-bank $>$.

${ }^{54}$ Lacsamana, Revolutionizing Feminism, 9.

${ }^{55}$ Grace Chang, Disposable Domestics: Immigrant Women Workers in the Global Economy (Cambridge, MA: South End Press, 2000), 123.

${ }^{56}$ Lacsamana, Revolutionizing Feminism, 55.
}

(c) 2020 Noelle Leslie G. Dela Cruz https://www.kritike.org/journal/issue 26/dela cruz june2020.pdf ISSN 1908-7330 


\section{FEMINIST CRITIQUE OF CARE-BASED POLITICAL THEORIES}

billion. ${ }^{57}$ Almost 10 percent of the national budget is dedicated to servicing the interest on this debt. 58

To help pay the national debt, the Philippine state relies on the labor of Filipino women; after all, women dominate the labor force both in exportmanufacturing production and migrant employment. ${ }^{59}$ However, this has not really benefited women in the Philippines, since the labor market remains highly segregated and they have only become stereotyped as naturally suited caregivers. ${ }^{60}$ Indeed, the continuing exploitation of Filipina migrant laborers is legendary. The tragic deaths of Flor Contemplacion in Singapore, Maricris Sioson in Japan, and, most recently, Joana Demafelis in Kuwait make headlines and cause public outrage, but only reactionary stopgap measures are put into place. ${ }^{61}$ While only a minority of Filipino migrant workers come home in a coffin, their widespread abuse and the violation of their human rights are well-documented. For example, in her interview-based study, Constable describes the situation of Filipino domestic workers in Hong Kong, where they are subjected to various forms of control and discipline by their employers, recruitment agencies, and the Chinese government, including being forced to eat leftovers, staying in a stifling and cramped room no bigger than a closet, not having access to communal places like the living room, being locked inside the house while the employers are away, and being made to cut their hair or not wear any makeup. ${ }^{62}$ Meanwhile, Liu presents the "embodied crises" of two migrant Filipino domestic workers in Taiwan. Elsa, a carer for her employers' elderly parents, was diagnosed with stage three breast cancer in the middle of her contract. Without the benefit of health care or paid leave, she was forced to return to the Philippines after accepting a termination fee from her employers, which was not enough to cover her

\footnotetext{
57 "Philippine external debt down to \$73.2B in Q1 2018," in Rappler (15 June 2018), $<$ https://www.rappler.com/business/205034-philippine-external-debt-q1-2018>.

${ }^{58}$ Department of Budget and Management, "2018 National Budget: A Budget that Reforms and Transforms," in DBM, <https://www.dbm.gov.ph/wpcontent/uploads/Our\%20Budget/2018/2018\%20QUICK\%20GLANCE\%201172018.pdf>, accessed 3 November 2018.

${ }^{59}$ Parreñas, "Gender Ideologies in the Philippines," 27.

60 Ibid., 29-30.

${ }^{61}$ Following the murder of Demafelis by her employers, Philippine President Rodrigo Duterte imposed a brief ban on labor deployment to Kuwait, which was lifted after a labor pact was signed between the two countries. See "Philippines' Duterte orders lifting of labor deployment ban to Kuwait," in Reuters (16 May 2018), <https://www.reuters.com/article/usphilippines-kuwait-labour/philippines-duterte-orders-lifting-of-labor-deployment-ban-tokuwait-idUSKCN1IH20R>.

${ }^{62}$ Nicole Constable, "Filipina Workers in Hong Kong Homes: Household Rules and Relations," Global Woman: Nannies, Maids, and Sex Workers in the New Economy, ed. by Barbara Ehrenreich and Arlie Russell Hochschild (New York: Henry Holt and Company, 2002), Kindle, loc. 2020-2500, passim.

(c) 2020 Noelle Leslie G. Dela Cruz

https://www.kritike.org/journal/issue 26/dela cruz june2020.pdf

ISSN 1908-7330
}

(cc) BY-NC-ND 
treatment and the needs of her family. ${ }^{63}$ Meanwhile, Jocelyn, who had sought work abroad in order to escape from her abusive husband in the Philippines, found herself escaping from her employers' house as well, where she had been subjected to 24-hour camera surveillance and sleep deprivation from working 20 hours a day. ${ }^{64}$ By far the worst places to be in for migrant domestics are the countries in the Middle East, which, among the top labor destinations for Filipinos, paid the lowest average wages and offered the least labor protection. ${ }^{65}$ In a 2010 study, Human Rights Watch documented the abuses suffered by migrant domestic workers in Kuwait, which included nonpayment of wages and overwork; sexual, physical, and psychological abuses; denial of adequate food and health care; passport confiscation; and forced confinement in the workplace. ${ }^{66}$

It will take so much more space than I have here to detail other cases of abuse suffered by Filipino migrant workers. However, this is only half of the picture. The other half is the story of the care drain in the Philippines as its citizens - the traditional care workers of society-leave the country en masse in order to support their families and the national economy. As Parreñas details in her study of the international division of reproductive labor, women who go abroad to take care of privileged dependents in developed countries, in turn employ poorer women in their country of origin to take care of the dependents that they themselves leave behind. ${ }^{67}$ But what of the dependents of the carers in the lowest status? Nothing is said about their fate. The children who overrun the narrow, garbage-strewn and pollution-choked streets, the beggars who weave in and out of traffic on the major thoroughfares, the out-of-school youth who are summarily executed in the Duterte administration's so-called war on drugs, the emaciated women and girls who are forced to sell unprotected sex, the soot-covered and often mentally imbalanced homeless people who wander the streets, the sick and elderly who have to line up for hours on end at understaffed public hospitals, the students who have to work part-time in order to afford private education - these are a common sight in the Philippines. This is a crisis that cannot be addressed by the care-based political theories crafted by philosophers in the Global North, inasmuch as their frameworks neglect the complicity of their own countries in sustaining this worldwide inequality and lack of care.

${ }^{63}$ Wen Liu, "The Embodied Crises of Neoliberal Globalization: The Lives and Narratives of Filipina Migrant Domestic Workers," in Women's Studies International Forum, 50 (2015), 83.

${ }^{64}$ Ibid., 85.

${ }^{65}$ Parreñas, "The Global Migration of Filipino Domestic Workers," 7.

${ }^{66}$ Priyanka Motaparthy, Walls at Every Turn: Abuse of Migrant Domestic Workers through Kuwait's Sponsorship System (New York: Human Rights Watch, 2010), 48-57.

${ }^{67}$ Parreñas, "The Reproductive Labour of Migrant Workers," 269.

(c) 2020 Noelle Leslie G. Dela Cruz

https://www.kritike.org/journal/issue 26/dela cruz june2020.pdf

ISSN 1908-7330

(cc) BY-NC-ND 


\section{FEMINIST CRITIQUE OF CARE-BASED POLITICAL THEORIES}

As the crisis is global in scope and most gravely affects developing countries, the philosophical, economic, and political proposals mentioned in the preceding section are inadequate and unworkable. The economic solution-the creation of a robust welfare state-underpins the other two solutions. Following a materialist analysis, the economic conditions of society tend to have a bottom-up effect on the philosophical and political ideas that prevail. But as we have seen, the Philippines cannot afford the provision of adequate welfare for its citizens, because its agricultural, labor, and fiscal resources are being siphoned off into other parts of the world. In light of the economic conditions, even an intellectual paradigm shift that revalues care and the concerns of the private sphere will not be enough. Recognizing the intrinsic value of care work, as well as adopting a critical attitude toward the public/private dichotomy, will remain largely the intellectual province of the privileged few.

\section{Coda: Questions to Ask toward a (Filipino) Political Philosophy of Care}

A care-based political theory that is applicable to the Philippine setting must significantly reframe the care crisis. To this end, the following preliminary questions point to meaningful philosophical directions:

On the value of care work:

- How significant is the conceptual distinction between direct or faceto-face dependency work and indirect or non-nurturant reproductive work? What accounts for the implicit hierarchy between these two types of care work? How should we conceive of their value? Does justice require equal compensation for all types of care work?

On agency and responsibility:

- What degree of responsibility should non-state actors like transnational companies and international lending institutions bear for the public welfare of citizens of developing countries?

- What degree of agency should be attributed to migrant care workers? What are the implications of diminished agency for immigration and labor law reforms?

- How should the gains from permanent residency and citizenship rights for migrant workers be measured against the losses from the care drain in their origin countries?

On the prospects for a transnational feminism: 
- Given the inequalities between women revealed by the global care crisis, can any common advocacies form the basis of a transnational feminism?

- To what extent does care work remain gendered? How useful are gender-based concepts such as the feminization of labor (and of the Philippines as a primer exporter of domestic workers)? Do such gender-based analyses obscure intersectional issues?

I enjoin Filipino philosophers interested in the global care crisis to reflect on these most pressing of questions.

Philosophy Department, De La Salle University, Manila, Philippines

\section{References}

Addati, Laura, Umberto Cattaneo, Valeria Esquivel, and Isabel Valarin, Care Work and Care Jobs for the Future of Decent Work (Geneva: International Labour Office, 2018).

Chang, Grace, Disposable Domestics: Immigrant Women Workers in the Global Economy (Cambridge, MA: South End Press, 2000).

Claassen, Rutger, "The Commodification of Care," in Hypatia: The Feminist Journal of Philosophy, 26:1 (2011).

Constable, Nicole, "Filipina Workers in Hong Kong Homes: Household Rules and Relations," Global Woman: Nannies, Maids, and Sex Workers in the New Economy, ed. by Barbara Ehrenreich and Arlie Russell Hochschild (New York: Henry Holt and Company, 2002), Kindle.

Crozier, G.K.D., "Care Workers in the Global Market: Appraising Applications of a Feminist Care Ethics," in The International Journal of Feminist Approaches to Bioethics, 3:1 (Spring 2010).

Department of Budget and Management, "2018 National Budget: A Budget that Reforms and Transforms," in DBM, $<$ https://www.dbm.gov.ph/wpcontent/uploads/Our\%20Budget/2018/2018\%20QUICK\%20GLANC E\%201172018.pdf $>$, accessed 3 November 2018.

Engster, Daniel, Justice, Care, and the Welfare State (Oxford: Oxford University Press, 2015).

"Rethinking Care Theory: The Practice of Caring and the Obligation to Care," in Hypatia: A Journal of Feminist Philosophy, 20:3 (Summer 2005). The Heart of Justice (Oxford: Oxford University Press, 2007). 
Fine, Michael, "Eva Feder Kittay: Dependency Work and the Social Division of Care," in The Palgrave Handbook of Social Theory in Health, Illness and Medicine, ed. by Fran Collyer (New York: Palgrave Macmillan, 2015).

Fine, Michael and Caroline Glendinning, "Dependence, Independence or Interdependence? Revisiting the Concepts of 'Care' and 'Dependency,', in Aging and Society, 25:4 (July 2005).

Folbre, Nancy, "Measuring Care: Gender, Empowerment, and the Care Economy," in Journal of Human Development, 7:2 (2006).

Hanes, Douglas William, "Left Out/Left Behind: On Care Theory's Other," in Hypatia: A Journal of Feminist Philosophy, 32:3 (May 2017).

Hankivsky, Olena, "Imagining Ethical Globalization: The Contributions of a Care Ethic," in Journal of Global Ethics, 2:1 (August 2006).

Held, Virginia, The Ethics of Care: Personal, Political, and Global (Oxford: Oxford University Press, 2006).

Isaksen, Lise Widding, Sambasivan Uma Devi, and Arlie Russell Hochschild, "Global Care Crisis: A Problem of Capital, Care Chain, or Commons?" in American Behavioral Scientist, 52:3 (2008).

Kittay, Eva Feder, Love's Labor: Essays on Women, Equality, and Dependency (New York and London: Routledge, 1999).

"The Global Heart Transplant and Caring Across National Boundaries," in The Southern Journal of Philosophy, XLVI (2008).

Kittay, Eva Feder, Bruce Jennings, and Angela A. Wasunna, “Dependency, Difference and the Global Ethic of Longterm Care," in The Journal of Political Philosophy, 13:4 (2005).

Lacsamana, Anne E., Revolutionizing Feminism: The Philippine Women's Movement in the Age of Terror (New York and London: Routledge, 2012).

Liu, Wen, "The Embodied Crises of Neoliberal Globalization: The Lives and Narratives of Filipina Migrant Domestic Workers," in Women's Studies International Forum, 50 (2015).

Motaparthy, Priyanka, Walls at Every Turn: Abuse of Migrant Domestic Workers through Kuwait's Sponsorship System (New York: Human Rights Watch, 2010).

Noddings, Nel, Starting at Home: Caring and Social Policy (Berkeley, Los Angeles, and London: University of California Press, 2002).

Parreñas, Rhacel Salazar, "Gender Ideologies in the Philippines," in The Force of Domesticity: Filipina Migrants and Globalization (New York and London: New York University Press, 2008).

"Patriarchy and Neoliberalism in the Globalization of Care," in The Force of Domesticity: Filipina Migrants and Globalization (New York and London: New York University Press, 2008).

(c) 2020 Noelle Leslie G. Dela Cruz

https://www.kritike.org/journal/issue 26/dela cruz june2020.pdf

ISSN 1908-7330

(cc) BY-NC-ND 
"The Global Migration of Filipino Domestic Workers," in Servants of Globalization: Migration and Domestic Work, 2nd ed. (Stanford: Stanford University Press, 2015).

"The International Division of Reproductive Labor," in Servants of Globalization: Migration and Domestic Work, 2nd ed. (Stanford: Stanford University Press, 2015).

“The Reproductive Labour of Migrant Workers," in Global Networks, 12:2 (2012).

“Philippine external debt down to \$73.2B in Q1 2018," in Rappler (15 June 2018), <https://www.rappler.com/business/205034-philippineexternal-debt-q1-2018>.

"Philippines' Duterte orders lifting of labor deployment ban to Kuwait," in Reuters (16 May 2018), <https://www.reuters.com/article/usphilippines-kuwait-labour/philippines-duterte-orders-lifting-oflabor-deployment-ban-to-kuwait-idUSKCN1IH20R>.

Raghuram, Parvati, "Locating Care Ethics Beyond the Global North," in ACME: An International Journal for Critical Geographies, 15:3 (2016).

Rivas, Ralf, "Persistent high inflation may slow down poverty reduction World Bank," in Rappler (4 October 2018), $<$ https://www.rappler.com/business/213517-high-inflation-slowdown-poverty-reduction-world-bank $>$.

Robinson, Fiona, Globalizing Care: Ethics, Feminist Theory, and International Relations (Boulder: Westview Press, 1999).

Rodriguez, Robyn Magalit, Migrants for Export: How the Philippine State Brokers Labor to the World (Minnesota: University of Minnesota Press, 2010).

Rummery, Kirstein and Michael Fine, "Care: A Critical Review of Theory, Policy and Practice," in Social Policy \& Administration, 46:3 (2012).

Sevenjuijsen, Selma, Citizenship and the Ethics of Care: Feminist Considerations on Justice, Morality and Politics (London and New York: Routledge, 1998).

Tronto, Joan C., "Beyond Gender Difference to a Theory of Care," in Signs: Journal of Women in Culture and Society, 12:4 (1987).

Caring Democracy: Markets, Equality, and Justice (New York and London: New York University Press, 2013).

Tyner, James A., Made in the Philippines: Gendered Discourses and the Making of Migrants (London and New York: RoutledgeCurzon, 2004).

Weir, Allison, "Global Care Chains: Freedom, Responsibility, and Solidarity," in The Southern Journal of Philosophy, 46 (2008). 